\title{
Systematic Review of Recent Lipidomics Approaches Toward Inflammatory Bowel Disease
}

\author{
Eun Goo Lee, Young Cheol Yoon, Jihyun Yoon, Seul Ji Lee, Yu-Kyoung Oh and Sung Won Kwon* \\ College of Pharmacy, Seoul National University, Seoul 08826, Republic of Korea
}

\begin{abstract}
Researchers have endeavored to identify the etiology of inflammatory bowel diseases, including Crohn's disease and ulcerative colitis. Though the pathogenesis of inflammatory bowel diseases remains unknown, dysregulation of the immune system in the host gastrointestinal tract is believed to be the major causative factor. Omics is a powerful methodological tool that can reveal biochemical information stored in clinical samples. Lipidomics is a subset of omics that explores the lipid classes associated with inflammation. One objective of the present systematic review was to facilitate the identification of biochemical targets for use in future lipidomic studies on inflammatory bowel diseases. The use of high-resolution mass spectrometry to observe alterations in global lipidomics might help elucidate the immunoregulatory mechanisms involved in inflammatory bowel diseases and discover novel biomarkers for them. Assessment of the characteristics of previous clinical trials on inflammatory bowel diseases could help researchers design and establish patient selection and analytical method criteria for future studies on these conditions. In this study, we curated literature exclusively from four databases and extracted lipidomics-related data from literature, considering criteria. This paper suggests that the lipidomics approach toward research in inflammatory bowel diseases can clarify their pathogenesis and identify clinically valuable biomarkers to predict and monitor their progression.
\end{abstract}

Key Words: Crohn's disease, Ulcerative colitis, Inflammatory bowel disease, Lipidomics, Mass spectrometry, Systematic review

\section{INTRODUCTION}

Crohn's disease (CD) and ulcerative colitis (UC) are inflammatory bowel disease (IBD) subtypes. The incidence of IBD subtypes is increasing worldwide and it is believed to be prevalent more in Caucasians (Baumgart and Carding, 2007). While they both cause chronic inflammation of the gastrointestinal tract, they differ in terms of their target sites and complications (Baumgart and Sandborn, 2007). IBD, categorized as an autoimmune disease, is all associated with genetic, environmental, and microbial factors (Baumgart and Carding, 2007) However, its pathogenic mechanism is unknown. Currently, IBD is diagnosed according to clinical manifestations, such as endoscopic, histological, and radiological findings (Baumgart and Sandborn, 2007). However, there is no standard diagnostic tool for IBD involving specific biochemical biomarkers. Furthermore, the etiology and pathological mechanisms of IBD have yet to be identified. Current therapies for treating IBD are not disease-specific, and thus there is the need to establish therapies for preventing initiation of the disease.
Omics is a powerful methodology to determine pathogenic mechanisms and detect diagnostic biomarkers. Omics analyzes biological molecules and its subcategories include genomics, transcriptomics, proteomics, and metabolomics (McShane et al., 2013). This approach provides insight into the diagnosis and pathological mechanisms of diseases. To understand the high-resolution mass spectrometry-based omics field, an extensive and deep understanding of analytic tools, such as liquid chromatography coupled with mass spectrometry (LC$\mathrm{MS}$ ), is required. Although thin-layer chromatography and nuclear magnetic resonance (NMR) are becoming less frequently used over time, direct combination of MS and LC-MS is the major approach employed in metabolomic studies (Cajka and Fiehn, 2014). The rapidly developing LC-MS-based metabolomic approaches are used to precisely detect the various signal variations in samples. Subsequently, computational analysis is used to distinguish only the significant metabolite signals from low effect or low abundance noise signals. A filtered and selected signal can be commonly used to compare metabolites between more than two different groups of sam-

\section{Open Access https://doi.org/10.4062/biomolther.2021.125}

This is an Open Access article distributed under the terms of the Creative Commons Attribution Non-Commercial License (http://creativecommons.org/licenses/by-nc/4.0/) which permits unrestricted non-commercial use, distribution, and reproduction in any medium, provided the original work is properly cited.
Received Jul 22, 2021 Revised Aug 17, 2021 Accepted Aug 18, 2021

Published Online Sep 27, 2021

\section{*Corresponding Author}

E-mail: swkwon@snu.ac.kr Tel: +82-2-880-7844 
ples. Further, this approach predicts and elucidates changes in pathways based on alterations in biological molecules and biomarkers. Metabolomics is the study of metabolites in living organs. It involves the investigation of global metabolic changes in sera and plasma, local metabolic modifications in tissues, or alterations in gut microbiome metabolism. Genes and proteins may indirectly affect changes in phenotype, whereas metabolites directly influence these changes. To understand metabolomics, MS is required to deconvolute the diverse number of metabolite groups (Roberts et al., 2008). A metabolomic approach to IBD can be informative because IBD is closely associated with genomic, environmental, and microbial factors. Moreover, the importance of the metabolomic approach on IBD was first discussed and published as a review paper (Storr et al., 2013).

Lipidomics is a branch of metabolomics that is being evaluated in the field of IBD research. In the field of the lipidomics, an ion peak with a unique $\mathrm{m} / \mathrm{z}$ and retention time is called a feature, and this feature is matched to a broad database to identify the specific lipid. Inflammatory response is mediated by several lipid subclasses that function as cellular messengers (Han, 2016). MS identifies and separates the number of carbons present in lipid chains containing as well as double bond number and even double bond location based on lipid subclasses. A recent study established specific biomarkers related to the inflammatory response by analyzing changes in lipid metabolism (Zhang et al., 2018). Researchers have begun to test untargeted lipidomics to explain the complex interactions between lipids and IBD. A broader range of metabolites can be observed using high-resolution MS combined with omics rather than other approaches. The present systematic review explores current progress in lipidomics-based IBD research and proposes novel research directions using this approach. This review also underscores the value of lipidomics in establishing IBD pathogenesis.

A lipidomics approach in IBD research could help facilitate disease diagnosis and identify novel candidate biomarkers for monitoring IBD progression. In this systematic review, we

\section{Systematic Review}

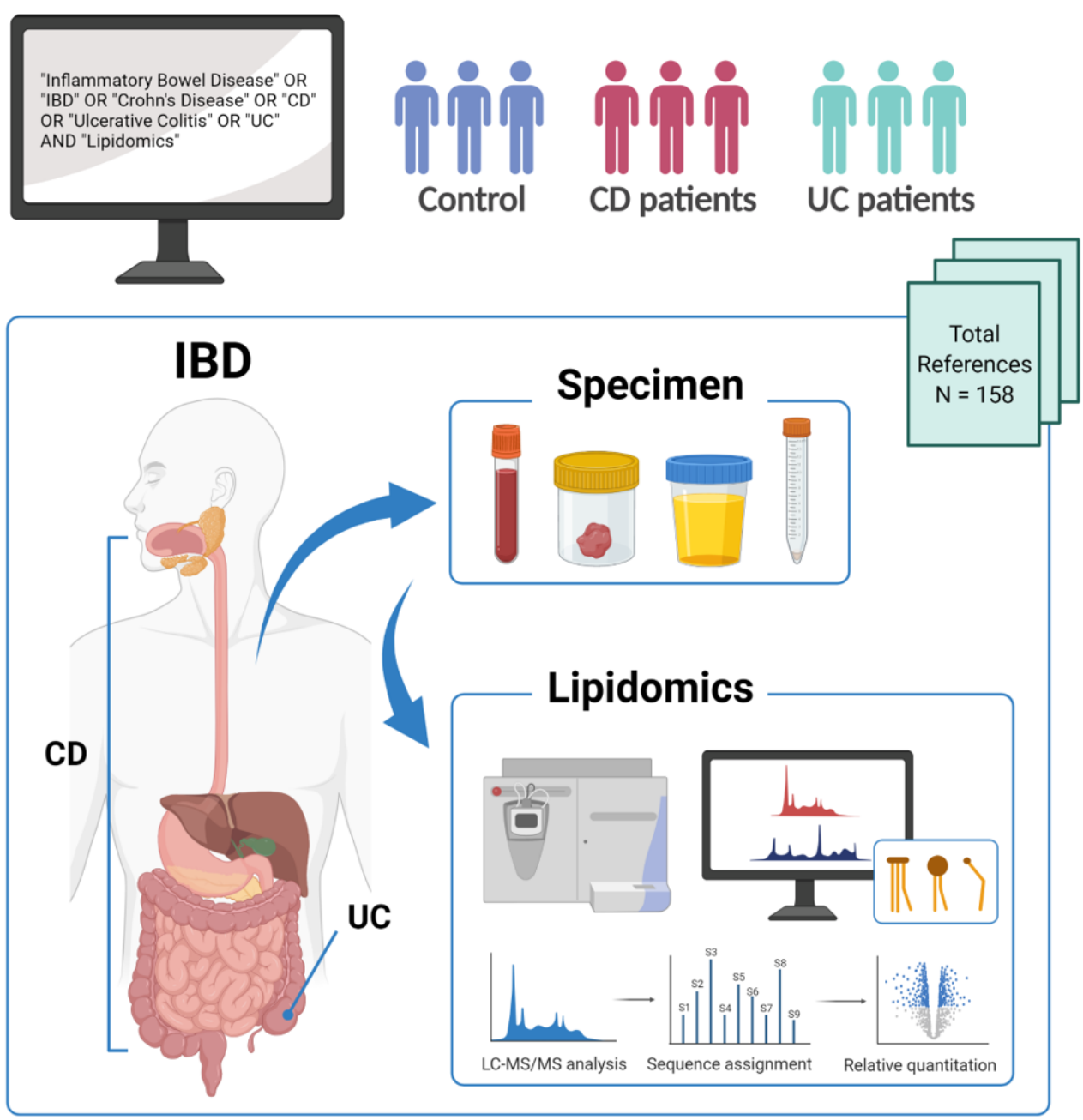

Fig. 1. Overview of systematic review on lipidomics in inflammatory bowel disease patients. This figure was created with BioRender (https://biorender.com). 
screened studies that examined human clinical samples containing candidate lipid biomarkers of any kind of IBD (Fig. 1). We then explored the feasibility of using lipids as a tool for IBD diagnosis and monitoring. An objective of this review was to evaluate the feasibility of developing a diagnostic method for IBD using novel lipid biomarkers rather than multiple techniques combined with clinical testing.

\section{LITERATURE SEARCH AND SELECTION}

This systematic review study was conducted on the basis of the PRISMA checklist (Moher et al., 2009). Papers were curated exclusively from English-based databases, such as PubMed (https://pubmed.ncbi.nlm.nih.gov), Clinical Trials (https://clinicaltrials.gov), Scopus (https://www.scopus.com), and Web of Science (https://www.webofknowledge.com). Reports were collected using search terms matching the objective of the present systematic review. The keywords used were "Inflammatory Bowel Disease" OR "IBD" OR "Crohn's Disease" OR "Ulcerative Colitis". The term "Lipidomics" was added to isolate studies applying this omics approach. As lipidomics is a type of metabolomics, the keyword "Metabolomics" was added. Finally, studies only containing significant lipid class data were considered. The literature list was updated via manual searches and collected starting from $6^{\text {th }}$ to $15^{\text {th }}$ of January 2021 and covered the literature published within January 2021.

Papers were sought by importing the foregoing keywords from the database and uploading them to Mendeley Desktop v. 1.19.4 (Mendeley, London, UK). The inclusion criteria were (1) clinical trials on CD, UC, or both; (2) sample analysis by MS; and (3) data outcomes-based mainly on lipidomics. The exclusion criteria were (1) non-human samples; (2) sample analysis by biological assay or NMR; and (3) no lipid-based data outcomes. Studies on humans could be observational or clinical; however, most eligible studies were observational. Article titles and abstracts were screened before exclusion. Studies on IBD that included preclinical or laboratory experiments were disqualified. Experimental designs based on MS analysis rather than biological assays were included. Two authors screened and selected the articles according to the PRISMA flow diagram.

Studies meeting the foregoing criteria were organized according to the Cochrane Collaboration (Furlan et al., 2009). Specific information for each study was extracted and tabulated. Patient cohorts, sample sizes, diagnostic methods, sample characteristics, and methods used were extracted. All studies except for one were cross-sectional. Intervention or drug treatment, treatment duration and blinding status were not considered.

After the selected keywords were entered into the databases, nineteen studies were found to match our inclusion criteria. A process flow for the literature search, screening, and selection is shown in Fig. 2. PubMed, Scopus, Clinical Trials, and Web of Science were the literature platforms, and 158 papers were searched. Of these, 36 duplicate papers were excluded, and the remaining 122 were screened by title and abstract. There were 103 papers that either did not meet our selection criteria or were inaccessible. Hence, 19 articles were

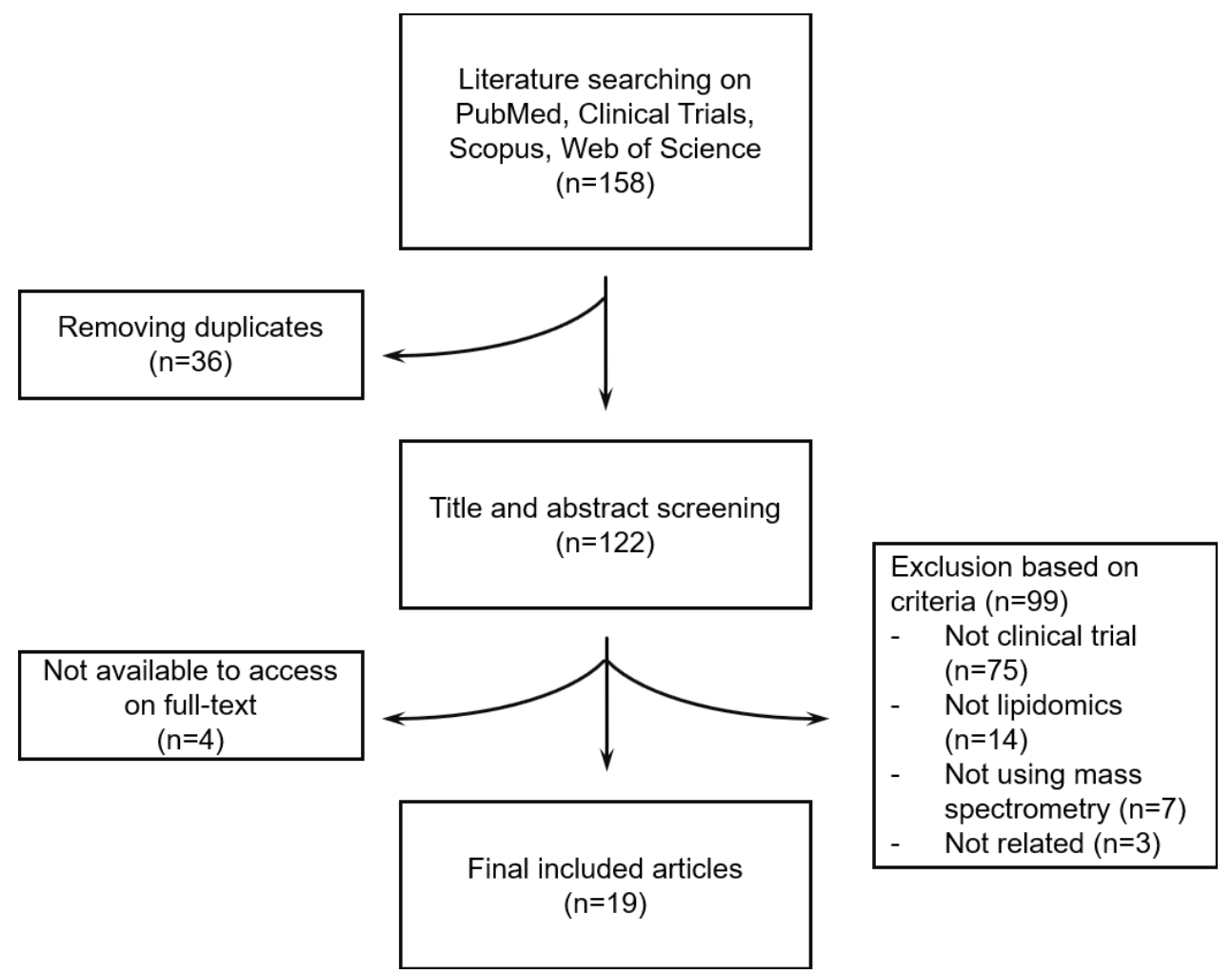

Fig. 2. Process flow for literature search on IBD clinical trials. 
retained. All selected studies were conducted on human clinical samples and used MS as the analytical platform.

Data extracted from the selected 19 studies are listed in Table 1. Two authors independently reviewed the extracted data based on the Cochrane Collaboration Back Review Group. Seventeen trials had observational or cross-sectional study designs, while two were case-control studies.

\section{ANALYSIS AND PRESENTATION OF EXTRACTED DATA}

A recent study attempted to determine the interaction between IBD and lipidomics (Titz et al., 2018). Another study tried to define a standardized nomenclature for lipid species detected by MS (Liebisch et al., 2013). The lipid classes and subclasses covered in this systematic review are organized in Table 2. Twelve of the 19 curated studies focused on lipidomics and were published within the past five years. All studies endeavoring to develop lipid biomarkers for IBD diagnosis and progression were approved by local ethics committees. Either the enrolled subjects or their parents provided informed consent. Participants were treated in these trials in accordance with the precepts of the Declaration of Helsinki. IBD was diagnosed based on clinical criteria. Four of the 19 studies did not explicitly describe the diagnostic tools or methods they used for IBD. The other 15 studies used endoscopy, histology, radiology, and occasionally laboratory data to corroborate and provide supportive information for prior clinical IBD diagnoses. When reports did not mention clinical diagnosis, it was assumed that it was nonetheless included along with endoscopic and histological examinations.

For all reports except one, patients were categorized as CD or UC based on clinical and histological criteria. In the other study, the experimental group comprised all patients with $C D$ and $\mathrm{UC}$ and they were collectively compared against healthy controls (Guan et al., 2020). In eight studies, CD and UC patients were individually compared with healthy controls. Horta et al. (2021) assessed IBD interventions and fatigue in the absence of a healthy control group. They designated the fatigue group as an experimental group and compared it against non-fatigued CD and non-fatigued UC "controls" (Horta et al., 2021). In another study, the experimental group was divided into colonic CD (CCD) and ileal CD (ICD) according to the lesion sites in the patients (Jansson et al., 2009). Diab and colleagues performed a lipidomic analysis on UC patients and divided them into treatment-naïve and deep remission groups (Diab et al., 2019).

The single prospective case-control study performed analyses on UC patients but did not interpret the study design (Pearl et al., 2014). UC patients were categorized as active or quiescent, and inflamed and uninflamed tissues were obtained from each active UC patient and paired. Prior research indicated that patient age influences IBD progress and symptoms. One observational study was conducted on children alone, while another was performed exclusively on adults over the age of 18 years (Sauer and Kugathasan, 2009; Ezri et al., 2012). Martin et al. (2016) conducted a metabolomics study on participants with an average age of 14 years. However, it was omitted from the present systematic review as it did not implement a lipidomics approach. It concluded that the early developmental abnormalities frequently observed in IBD pa- tients could be explained by malabsorption and delayed onset of puberty. The authors stated that according to NMR-based metabolomics, urinary urea and phenylacetylglutamine are associated with malnutrition in IBD and are key factors predicting disease progression (Martin et al., 2016).

Several studies attempted to use the various biological sample specimens to identify the etiology and pathogenesis of IBD in immunocompromised patients. The early lesions in IBD resemble those observed in other diseases. Hence, it is difficult to diagnose IBD until they have become advanced. Hence, noninvasive, convenient, and highly accurate diagnostic methods are required for these conditions and are being explored by numerous specialists. Blood is an ideal source of biological samples as it is easier and simpler to collect than other types of tissue. By the way, tissue samples harvested from lesion sites are also compatible with blood samples for their representativeness. However, tissue samples can also reveal the effects of diet and gut microbiome on alterations in the lipid constitution. Over half of the studies selected here used blood as an analytical and diagnostic sample (Fig. 3B). Blood specimens were often collected in many clinical examinations as well. Although blood sampling is invasive, it requires no preparatory steps, such as medication or anesthesia (Gallagher et al., 2021). However, seven of the studies curated here used intestinal tissue as analytical samples. The endoscopy procedure often includes a biopsy, which facilitates tissue sample collection. Fecal samples may also be collected non-invasively. One study examined primary macrophages isolated from the blood of participants (Sewell et al., 2012). Urine samples may also contain endogenous metabolites. One study measured urinary hippurate levels in CD patients but did not focus on other sample specimens and other lipidomes (Williams et al., 2010). The major sample specimen to be used for studies has not been determined, and the necessity of both diagnoses of the disease and discriminating $C D$ and $\mathrm{UC}$ is growing.

In the present systematic review, only studies using MS analysis were selected, as MS is one of the most used approaches in the lipidomics field (Cajka and Fiehn, 2014). $\mathrm{LC}-\mathrm{MS} / \mathrm{MS}$, triple quadrupole (QQQ) MS, quadrupole timeof-flight (Q-TOF) MS, and linear trap quadrupole (LTQ) were used in $71 \%$ of the studies (Fig. 3C). Usually, Q-TOF and LTQ are widely used in untargeted lipidomics of various diseases, and $Q Q Q$ is used for the targeted lipidomics of already known lipids. Unnecessary fragmentation of interesting metabolites facilitates the delicate analysis and enables easier interpretation. Gas chromatography/quadrupole (GC-Q) is frequently used to analyze fatty acids (Van Nuenen et al., 2004). Fatty acid analysis using LC-MS has the disadvantage of low selectivity and solvent consumption (Roberts et al., 2008). Further samples are required to pass through the derivatization step before analysis. Hence, we included studies that used GC-MS to identify and categorize fatty acids. One study used Fouriertransform ion cyclotron resonance (FT-ICR)/MS.

In the $21^{\text {st }}$ century, the incidence of IBD has increased globally, but it varies by ethnicity and nationality ( $\mathrm{Ng}$ et al., 2017). The present review indicated that the incidence of IBD was the highest in Europe and North America between 1990 and 2016. The prevalence of IBD has increased with industrialization in Asia as well. Therefore, the results of lipidomic studies on IBD patients may vary by cohort nationality. This systematic review showed that $74 \%$ of all trials were conducted in Europe 
Table 1. Demographic characteristics extracted from studies included in systematic review of IBD

\begin{tabular}{|c|c|c|c|c|c|c|c|c|c|}
\hline \multirow{2}{*}{ Author (year) } & \multirow{2}{*}{ Cohort } & \multicolumn{3}{|c|}{ IBD } & \multicolumn{2}{|c|}{ Control } & \multirow{2}{*}{ Diagnosis } & \multirow{2}{*}{ Sample } & \multirow{2}{*}{ Method } \\
\hline & & Type & Number & $\operatorname{Sex}(M / F)$ & Number & $\operatorname{Sex}(M / F)$ & & & \\
\hline Manfredi et al. (2019) & Italy & $\begin{array}{l}\text { CD } \\
\text { UC }\end{array}$ & $\begin{array}{l}15 \\
13\end{array}$ & $\begin{array}{l}7 / 8 \\
8 / 5\end{array}$ & 17 & NA & $\begin{array}{l}\text { Clinical } \\
\text { Endoscopic } \\
\text { Histological }\end{array}$ & Serum & GC-TOF \\
\hline Iwatani et al. (2020) & Japan & $\begin{array}{l}\text { CD } \\
\text { UC }\end{array}$ & $\begin{array}{l}20 \\
20\end{array}$ & $\begin{array}{l}20 / 0 \\
20 / 0\end{array}$ & 10 & $10 / 0$ & $\begin{array}{l}\text { Clinical } \\
\text { Endoscopic } \\
\text { Histological } \\
\text { Radiological }\end{array}$ & Plasma & UPLC-MS/MS \\
\hline Horta et al. (2021) & Spain & $\begin{array}{l}\text { Fatigue CD } \\
\text { Fatigue UC }\end{array}$ & $\begin{array}{r}14 \\
9\end{array}$ & $\begin{array}{l}6 / 8 \\
3 / 6\end{array}$ & $\begin{array}{l}13 \\
11\end{array}$ & $\begin{array}{l}6 / 7 \\
5 / 6\end{array}$ & NA & Plasma & HPLC-QTOF \\
\hline Guan et al. (2020) & China & $\mathrm{CD} / \mathrm{UC}$ & 99 & $73 / 26$ & 51 & $30 / 21$ & $\begin{array}{l}\text { Clinical } \\
\text { Histological }\end{array}$ & Plasma & UPLC-QTOF \\
\hline Daniluk et al. (2019) & Poland & $\begin{array}{l}\text { CD } \\
\text { UC }\end{array}$ & $\begin{array}{l}9 \\
9\end{array}$ & $\begin{array}{l}4 / 5 \\
4 / 5\end{array}$ & 10 & $5 / 5$ & NA & Serum & UPLC-QTOF \\
\hline Diab et al. (2019) & Norway & UC & 33 & $23 / 10$ & 14 & $9 / 5$ & $\begin{array}{l}\text { Clinical } \\
\text { Endoscopic } \\
\text { Histological }\end{array}$ & Tissue & UPLC-QTOF \\
\hline Fan et al. (2015) & Australia & $\begin{array}{l}\text { CD } \\
\text { UC }\end{array}$ & $\begin{array}{l}24 \\
16\end{array}$ & $\begin{array}{r}15 / 9 \\
9 / 7\end{array}$ & 84 & $39 / 45$ & $\begin{array}{l}\text { Clinical } \\
\text { Endoscopic } \\
\text { Histological } \\
\text { Radiological } \\
\text { Laboratory }\end{array}$ & Plasma & HPLC-QTRAP \\
\hline $\begin{array}{l}\text { Bazarganipour et al. } \\
\text { (2019) }\end{array}$ & Germany & UC & 98 & $51 / 47$ & 25 & NA & Clinical & $\begin{array}{l}\text { Tissue } \\
\text { Plasma }\end{array}$ & $\begin{array}{l}\text { HPLC-QQQ } \\
\text { UPLC-QTOF }\end{array}$ \\
\hline Jansson et al. (2009) & Sweden & $\begin{array}{l}\text { CCD } \\
\text { ICD }\end{array}$ & $\begin{array}{l}8 \\
6\end{array}$ & $\begin{array}{l}6 / 2 \\
3 / 3\end{array}$ & 22 & $10 / 12$ & Clinical & Feces & ICR-FT \\
\hline Murgia et al. (2018) & Italy & $\begin{array}{l}\text { CD } \\
\text { UC }\end{array}$ & $\begin{array}{l}50 \\
78\end{array}$ & $\begin{array}{l}22 / 28 \\
47 / 31\end{array}$ & 60 & $39 / 21$ & $\begin{array}{l}\text { Clinical } \\
\text { Endoscopic } \\
\text { Histological } \\
\text { Radiological }\end{array}$ & Plasma & $\begin{array}{l}\text { UPLC-/DTIM-QTOF } \\
\text { UPLC-QQQ }\end{array}$ \\
\hline Ehehalt et al. (2004) & Germany & $C D$ & 7 & $3 / 4$ & 21 & $11 / 10$ & $\begin{array}{l}\text { Endoscopic } \\
\text { Histological }\end{array}$ & Tissue & $Q Q Q$ \\
\hline Bene et al. (2006) & Hungary & UC & 44 & $25 / 19$ & 44 & $20 / 24$ & $\begin{array}{l}\text { Clinical } \\
\text { Endoscopic } \\
\text { Histological } \\
\text { Laboratory }\end{array}$ & Plasma & HPLC-QQQ \\
\hline Pearl et al. (2014) & UK & $\begin{array}{l}\text { UC } \\
\text { Paired UC }\end{array}$ & $\begin{array}{l}85 \\
54\end{array}$ & $\begin{array}{l}43 / 42 \\
26 / 28\end{array}$ & $\begin{array}{l}69 \\
54\end{array}$ & $\begin{array}{l}35 / 34 \\
26 / 28\end{array}$ & $\begin{array}{l}\text { Endoscopic } \\
\text { Histological }\end{array}$ & Tissue & $\begin{array}{l}\text { GC-MS } \\
\text { UPLC-LTQ }\end{array}$ \\
\hline Braun et al. (2009) & Germany & $\begin{array}{l}\mathrm{CD} \\
\mathrm{UC}\end{array}$ & $\begin{array}{l}10 \\
21\end{array}$ & $\begin{array}{l}2 / 8 \\
9 / 12\end{array}$ & 29 & NA & $\begin{array}{l}\text { Clinical } \\
\text { Endoscopic } \\
\text { Histological }\end{array}$ & Tissue & QQQ \\
\hline Scoville et al. (2018) & US & $\begin{array}{l}\mathrm{CD} \\
\mathrm{UC}\end{array}$ & $\begin{array}{l}20 \\
20\end{array}$ & $\begin{array}{c}9 / 11 \\
12 / 8\end{array}$ & 20 & $9 / 11$ & $\begin{array}{l}\text { Clinical } \\
\text { Histological }\end{array}$ & Serum & UPLC-LTQ \\
\hline Tefas et al. (2020) & Romania & $C D$ & 5 & $2 / 3$ & 24 & $10 / 14$ & $\begin{array}{l}\text { Clinical } \\
\text { Endoscopic } \\
\text { Histological } \\
\text { Serological }\end{array}$ & Serum & UPLC-QTOF \\
\hline Masoodi et al. (2013) & UK & UC & 54 & $26 / 28$ & 42 & NA & $\begin{array}{l}\text { Endoscopic } \\
\text { Histological }\end{array}$ & Tissue & UPLC-LTQ \\
\hline Sewell et al. (2012) & UK & $C D$ & 5 & $1 / 4$ & 5 & $3 / 2$ & NA & $\begin{array}{c}\text { Tissue, } \\
\text { Cell }\end{array}$ & $\begin{array}{l}\text { QQQ } \\
\text { HPLC-QQQ }\end{array}$ \\
\hline Lai et al. (2019) & US & $\begin{array}{l}\text { Active CD } \\
\text { Inactive CD }\end{array}$ & $\begin{array}{l}10 \\
10\end{array}$ & $\begin{array}{l}5 / 5 \\
5 / 5\end{array}$ & 10 & $5 / 5$ & NA & Serum & UPLC-QTOF \\
\hline
\end{tabular}


Table 2. Lipid class abbreviations based on LIPID MAPS categories

\begin{tabular}{|c|c|c|c|}
\hline \multicolumn{4}{|c|}{ Lipid } \\
\hline Class-Common name & Abbreviation & Subclass & Abbreviation \\
\hline \multirow[t]{4}{*}{ Fatty acyl } & \multirow[t]{4}{*}{ FA } & Fatty acid & FA \\
\hline & & Eicosanoids & -- \\
\hline & & Polyunsaturated fatty acid & PUFA \\
\hline & & Acyl carnitine & -- \\
\hline \multirow[t]{3}{*}{ Glycerolipid } & \multirow[t]{3}{*}{$\mathrm{GL}$} & Monoacylglycerol & MG \\
\hline & & Diacylglycerol & DG \\
\hline & & Triacylglycerol & TG \\
\hline \multirow[t]{9}{*}{ Glycerophospholipid } & \multirow[t]{9}{*}{ GP } & Phosphatidic acid & PA \\
\hline & & Phosphatidylcholine & $\mathrm{PC}$ \\
\hline & & Lysophosphatidylcholine & LPC \\
\hline & & Phosphatidylethanolamine & PE \\
\hline & & Lysophosphatidylethanolamine & LPE \\
\hline & & Phosphatidylglycerol & $P G$ \\
\hline & & Phosphatidylinositol & $\mathrm{PI}$ \\
\hline & & Phosphatidylserine & PS \\
\hline & & Lysophosphatidylserine & LPS \\
\hline \multirow[t]{4}{*}{ Sphingolipid } & \multirow[t]{4}{*}{ SL } & Ceramide & Cer \\
\hline & & Ceramide-1-phosphate & C1P \\
\hline & & Sphingoid-1-phosphate & S1P \\
\hline & & Sphingomyelin & SM \\
\hline
\end{tabular}

A

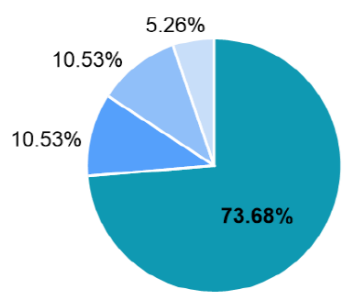

B

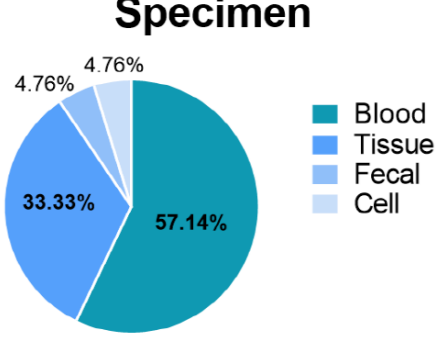

C

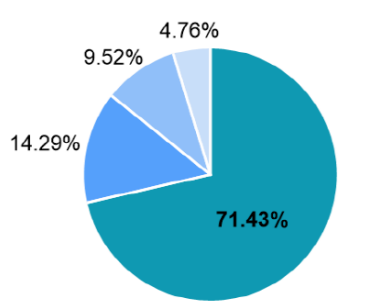

LC-MS/MS

MS/MS

GC-MS

MS

\section{Pathway analysis E Biomarker candidate}
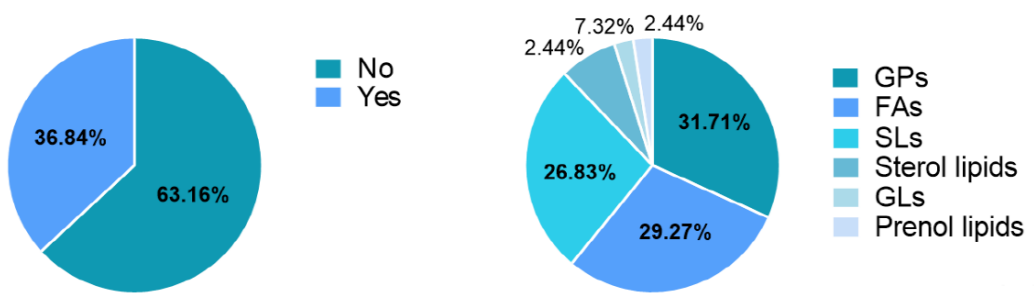

Fig. 3. Study design and selection of included studies. (A) Cohort; (B) Specimen; (C) Platform; (D) Pathway analysis; (E) Biomarker candidate.

(Fig. 3A). National and regional differences in dietary habits partially explain variations in the relative risk of IBD among populations (Molodecky et al., 2011).

Analysis and comparison of metabolic pathways can identify those which have substantially changed in response to IBD. Seven studies conducted pathway analysis. They investigated altered metabolic pathways using previously annotated lipid profiles (Fig. 3D). Six studies reported relative changes in arachidonic and fatty acid metabolism in IBD. Of these, two reported significant alterations in glycerophospholipid and sphingolipid metabolism in IBD. The eicosanoid precursor arachidonic acid is associated with proinflammatory responses (Dennis and Norris, 2015). Detection of significantly changed lipid profiles and introduction of lipidomic datasets into pathway analyses will enable the prediction of dysregulation in certain metabolic pathways and elucidate the underlying molecu- 
lar mechanisms of IBD (Huan et al., 2018). Pathway analyses are recommended in future lipidomic studies on IBD to identify the metabolic changes associated with it. Current advances in the novel, simplified algorithms will facilitate pathway analysisbased research.

Each study included in the present systematic review proposed candidate lipid biomarkers that could be used to diagnose and stage IBD. Table 3 categorizes these prospective lipid biomarkers (Liebisch et al., 2013). Glycerophospholipids (GPs), sphingolipids (SLs), and fatty acyls (FAs) were proposed in several studies, while GLs, prenols, and sterols were each recommended only once (Fig. 3E). Certain studies conducted untargeted analyses and evaluated all lipid classes. Others limited their investigations to a few selected lipid categories. The results of the studies reviewed here suggest a consensus within the academic community regarding the significance of GPs, SLs, and FAs in IBD progression. So far, several protein biomarkers associated with IBD have been identified. However, none of them can differentiate between the two subtypes of IBD, and diagnosis is difficult in the early stage (Bennike et al., 2014). Instead of protein markers, we suggest using lipid subclasses for discriminating between the two subtypes of IBD, CD and UC. Based on this suggestion, a detailed and in-depth targeted lipidomics of the specific subclasses is needed.

\section{GPs}

Certain studies targeted the phosphatidylcholines (PCs) and LPC subclasses of GPs in CD and UC patients. GPs can generally form $[\mathrm{M}+\mathrm{H}]^{+}$ion and $[\mathrm{M}-\mathrm{H}]^{-}$ion in positive and negative mode detection, respectively, during electrospray ionization, except phosphatidic acids (PAs). Some GP subclasses, including PAs have ' -1 ' negative net charge at $\mathrm{pH} 7.0$ in solution, and these subclasses can be better detected in negative mode detection. Researchers determine the appropriate ionization mode, positive or negative, in detecting the desired GP subclasses. Biopsy specimens obtained through colonoscopy were analyzed by $Q Q Q$ and revealed that PCs were substantially reduced in UC patients compared with CD patients and healthy controls. This finding confirms the protective function of colonic mucus in UC patients and raises the prospect of identifying various lipid subclasses via a novel analytical platform (Ehehalt et al., 2004). In Ehehalt's study, PC 16:0/18:1, PC 16:0/18:2, PC 18:0/18:1, PC 18:0/18:2, LPC 16:0, and LPC 18:0 were the most abundant species. Every abundant $P C$ in mucus had one unsaturated side chain. PCs increase the hydrophobicity of the luminal side of the mucus layer and may trigger an anti-inflammatory response at the mucosal barrier (Schneider et al., 2010). In the lipidomic study focusing on GPs in CD and UC patients and healthy controls, both PCs and LPCs were significantly lower at all UC lesion sites. Braun et al. (2009) reported significant decreases in PCs at two lesion sites in UC patients. Hence, PC synthesis and secretion are considerably lower in UC patients than in CD patients and healthy controls (Braun et al., 2009). In male UC patients, there were significant increases in PAs, phosphatidylserines (PSs), and lysophosphatidylserines (LPSs) compared with those in healthy controls. Moreover, PSs and LPSs were higher in male CD patients than in healthy controls. However, this study had a Olimitation of analyzing only young male patients
(Iwatani et al., 2020). The other studies presenting GP biomarkers are presented in Table 4.

\section{FAs}

FAs constitute a lipid category classified by the International Lipid Classification and Nomenclature Committee and include subclasses, such as free fatty acids and polyunsaturated fatty acids (PUFAs) (Fahy et al., 2009; Liebisch et al., 2013). Fatty acid subclasses are detected in [M-H] form during electrospray ionization. Eicosanoids derived from PUFAs may be either proinflammatory or anti-inflammatory (Dennis and Norris, 2015). Several studies revealed that free fatty acids and PUFAs can discriminate IBD patients from the control group. Table 5 presents the specific FA biomarker candidates identified by the included studies. Jansson et al. (2009) conducted a study on CD in identical twins. The study recruited pairs of healthy twins, pairs consisting of one healthy twin and one presenting with $C D$, and pairs of twins presenting with $\mathrm{CD}$. The symptomatic patients were categorized either as ileal CD (ICD) or colonic CD (CCD) cases depending on the lesion sites. The metabolomics, lipidomics, and pathway analyses indicated that six fatty acids and four arachidonic acids were candidate biomarkers. Six fatty acids were markedly increased in the ICD patients but did not provide twin-specific discrimination. Where UC patients alone were profiled, carnitine esters were evaluated. The levels of total carnitine esters were lower in the UC patients than in the healthy controls, but four long-chain fatty acid (LCFA) carnitine esters were lower in the healthy group. Carnitine is a carrier and transporter of LCFAs. Thus, UC pathogenesis might be associated with the combination of various lengths of fatty acid chains connected to acyl carnitines (Bene et al., 2006). This report focused exclusively on FAs associated with UC and was the only prospective case-control study reviewed here. Moreover, it provided no rationale for using this study design. As it is known that PUFAs participate in inflammation, GC-Q and UPLC-LTQ were used to identify esterified and non-esterified fatty acids. Arachidonic acid, docosahexaenoic acid, and docosapentaenoic acid were significantly elevated in patients with active UC compared with levels in healthy controls. Furthermore, the three foregoing FA markers were considerably higher in the inflamed tissues than in the non-inflamed tissues of the same patients with active UC. The same results were obtained by endoscopic examination. Inflammation worsened with UC progression, and it was confirmed that PUFAs were implicated in this mechanism (Pearl et al., 2014).

\section{SLs}

SLs are representative membrane lipids and play central roles in maintaining and balancing the $\mathrm{Gl}$ immune system (Bryan et al., 2016). The functions of SLs in the intestine are only partially understood. Nevertheless, SLs play important roles in structural integrity and generate lipid messengers (Duan and Nilsson, 2009). Certain studies focused specifically on the involvement of SLs in IBD. The roles of ceramide (Cer), ceramide-1-phosphate (C1P), sphingomyelin (SM; $\mathrm{Sph}$ ), and sphingoid-1-phosphate (S1P) in IBD development were examined (Guan et al., 2020). It was concluded that Cer 
Table 3. Biomarker candidates and pathway analyses in studies included in systematic review of IBD

\begin{tabular}{|c|c|c|c|c|c|}
\hline Author (year) & Cohort & IBD type & Sample & Biomarker candidate & Pathway analysis \\
\hline Manfredi et al. (2019) & Italy & $C D$ & Serum & $\begin{array}{l}\text { Fatty acid } \\
\text { PUFA }\end{array}$ & No \\
\hline Iwatani et al. (2020) & Japan & $C D$ & Plasma & PS & No \\
\hline \multirow[t]{7}{*}{ Horta et al. (2021) } & Spain & Fatigue CD & Plasma & PC & Yes \\
\hline & & & & LPC & \\
\hline & & & & PE & \\
\hline & & & & $\mathrm{PI}$ & \\
\hline & & & & PS & \\
\hline & & & & SM & \\
\hline & & & & Eicosanoid & \\
\hline \multirow[t]{5}{*}{ Guan et al. (2020) } & China & $\mathrm{CD} / \mathrm{UC}$ & Plasma & FA & Yes \\
\hline & & & & GP & \\
\hline & & & & $\mathrm{SL}$ & \\
\hline & & & & Prenol lipid & \\
\hline & & & & Sterol lipid & \\
\hline \multirow[t]{2}{*}{ Daniluk et al. (2019) } & Poland & CD & Serum & GP & Yes \\
\hline & & & & Cer & \\
\hline \multirow[t]{3}{*}{ Diab et al. (2019) } & Norway & UC & Tissue & PC & No \\
\hline & & & & SM & \\
\hline & & & & Cer & \\
\hline \multirow[t]{6}{*}{ Fan et al. (2015) } & Australia & $C D$ & Plasma & PC & No \\
\hline & & & & Ether PC & \\
\hline & & & & Ether PE & \\
\hline & & UC & & LPE & \\
\hline & & & & PS & \\
\hline & & & & Cer & \\
\hline \multirow[t]{6}{*}{ Bazarganipour et al. (2019) } & Germany & UC & Plasma & Fatty acid & No \\
\hline & & & & LPC & \\
\hline & & & & SM & \\
\hline & & & Tissue & Cer & \\
\hline & & & & TG & \\
\hline & & & & Eicosanoid & \\
\hline Jansson et al. (2009) & Sweden & CCD & Feces & FA & Yes \\
\hline \multirow[t]{5}{*}{ Murgia et al. (2018) } & Italy & $C D$ & Plasma & Fatty acid & No \\
\hline & & & & $\mathrm{PC}$ & \\
\hline & & & & LPC & \\
\hline & & & & PS & \\
\hline & & & & TG & \\
\hline \multirow[t]{2}{*}{ Ehehalt et al. (2004) } & Germany & $C D$ & Tissue & PC & No \\
\hline & & & & LPC & \\
\hline Bene et al. (2006) & Hungary & UC & Plasma & AcylCar & No \\
\hline Pearl et al. (2014) & UK & UC & Tissue & Eicosanoid & No \\
\hline \multirow[t]{3}{*}{ Braun et al. (2009) } & Germany & $C D$ & Tissue & PC & No \\
\hline & & & & LPC & \\
\hline & & & & SM & \\
\hline Scoville et al. (2018) & US & $C D$ & Serum & FA & Yes \\
\hline \multirow[t]{5}{*}{ Tefas et al. (2020) } & Romania & $C D$ & Serum & FA & Yes \\
\hline & & & & PC & \\
\hline & & & & LPC & \\
\hline & & & & SM & \\
\hline & & & & DG & \\
\hline Masoodi et al. (2013) & UK & UC & Tissue & Eicosanoid & No \\
\hline \multirow[t]{2}{*}{ Sewell et al. (2012) } & UK & $C D$ & Tissue, Cell & $\mathrm{PI}$ & No \\
\hline & & & & PC & \\
\hline \multirow[t]{2}{*}{ Lai et al. (2019) } & US & Active CD & Serum & Fatty acid & Yes \\
\hline & & & & Acylcarnitine & \\
\hline
\end{tabular}


Table 4. GP biomarker candidates in studies included in the systematic review of IBD

\begin{tabular}{|c|c|c|c|c|}
\hline Author (year) & IBD type & Sample & GP biomarker candidate & Additional description \\
\hline Iwatani et al. (2020) & CD & Plasma & $\begin{array}{l}\text { PSa } 40: 3, \text { PSa } 38: 3 \text {, PSa } 42: 4 \\
\text { LPS 18:0 }\end{array}$ & \\
\hline Horta et al. (2021) & $C D$ & Plasma & $\begin{array}{l}\text { PI 14:0/18:1 } \\
\text { LPI 16:0, LPI 18:0, LPI 18:1 } \\
\text { PC 10:0/26:2, PC 12:0/22:2, PC 12:0/24:2, } \\
\text { PC 14:1/22:4, PC 16:1/16:0, PC 14:0/14:0, } \\
\text { PC 14:0/16:0, PC 16:0/18:1, PC 18:1/18:0 } \\
\text { LPC 16:0 } \\
\text { Plasmenyl PC P-14:0, Plasmenyl PC P-20:0 } \\
\text { Plasmenyl PC O-18:0, Plasmenyl PC } \\
\text { O-20:0 } \\
\text { Plasmenyl PE P-18:0 } \\
\text { PE-NMe2 16:0/16:0 } \\
\text { PS 10:0/18:0 } \\
\text { PA 16:0/26:2 } \\
\text { Methyl PA 14:0/20:2 }\end{array}$ & $\begin{array}{l}\text { GP biomarker candidates having odd } \\
\text { carbon number of fatty acid chain } \\
\text { are excluded. } \\
\text { FA biomarker candidates in the } 50 \\
\text { most discriminant biomarkers. }\end{array}$ \\
\hline Guan et al. (2020) & CD/UC & Plasma & $\begin{array}{l}\text { LPA } 18: 2 \\
\text { LPC } 20: 4, \text { LPC } 22: 1 \text {, LPC } 24: 1\end{array}$ & \\
\hline Daniluk et al. (2019) & CD/UC & Serum & $\begin{array}{l}\text { PC } 36: 6, \text { PC } 16: 0 / 20: 3, \text { PC } 16: 0 / 20: 4 \\
\text { LPC } 14: 0 \text { (sn-1, sn-2), LPC 16:0, LPC 16:1 } \\
\text { (sn-1, sn-2), LPC 18:1 (sn-1, sn-2), LPC } \\
\text { 18:2 (sn-1, sn-2), LPC 18:3, LPC 20:0, } \\
\text { LPC } 20: 2 \text {, LPC 20:3, LPC 20:4, LPC 20:5, } \\
\text { LPC } 22: 4 \text {, LPC } 22: 5 \text {, LPC } 22: 6 \\
\text { LPA 18:2, LPA } 20: 4\end{array}$ & $\begin{array}{l}\text { GP biomarker candidates having odd } \\
\text { carbon number of fatty acid chain } \\
\text { are excluded. }\end{array}$ \\
\hline Diab et al. (2019) & UC & Tissue & PE 38:3 & \\
\hline Fan et al. (2015) & CD/UC & Plasma & $\begin{array}{l}\text { Alkylphosphatidylcholine } \\
\text { Alkenylphosphatidylcholine } \\
\text { Lysoalkylphosphatidylcholine } \\
\text { Alkylphosphatidylethanolamine } \\
\text { Alkenylphosphatidylethanolamine } \\
\text { Phosphatidylserine }\end{array}$ & $\begin{array}{l}\text { Lysoalkylphosphatidylcholine, } \\
\text { alkenylphosphatidylethanolamine, } \\
\text { phosphatidylserine subclass were } \\
\text { relatively significant only between } \\
\text { CD versus control group. }\end{array}$ \\
\hline $\begin{array}{l}\text { Bazarganipour et al. } \\
\text { (2019) }\end{array}$ & UC & Plasma & $\begin{array}{l}\text { LPC } 16: 0, \text { LPC } 18: 1 \text {, LPC } 18: 2, \text { LPC } 18: 3 \\
\text { LPC } 20: 0 \text {, LPC } 24: 0 \\
\text { LPE } 18: 1, \text { LPE } 18: 2\end{array}$ & $\begin{array}{l}\text { Although lipidomic analysis was done } \\
\text { by using both plasma and tissue } \\
\text { samples, GP subclass was revealed } \\
\text { only in plasma samples. }\end{array}$ \\
\hline Murgia et al. (2018) & $C D$ & Plasma & 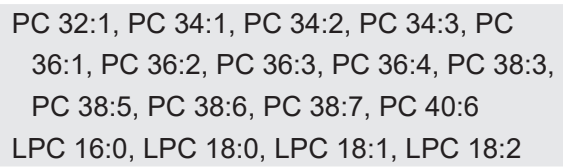 & \\
\hline Ehehalt et al. (2004) & $C D$ & Tissue & $\begin{array}{l}\text { PC } 34: 1, \text { PC } 34: 2, \text { PC } 36: 1, \text { PC } 36: 2 \\
\text { LPC } 16: 0, \text { LPC } 18: 0\end{array}$ & \\
\hline Braun et al. (2009) & CD/UC & $\begin{array}{l}\text { Ileal Mucus } \\
\text { Tissue } \\
\text { Colonic Mucus } \\
\text { Tissue }\end{array}$ & $\begin{array}{l}\text { PC } 32: 0, \text { PC } 34: 2 \\
\text { PC } 32: 0, \text { PC } 34: 2, \text { PC } 36: 1, P C 36: 2, P C \\
36: 4\end{array}$ & $\begin{array}{l}\text { PC } 34: 2 \text { can discriminate only } \\
\text { between UC versus control. } \\
\text { PC } 36: 2,36: 4 \text { can discriminate only } \\
\text { between UC versus control. }\end{array}$ \\
\hline Tefas et al. (2020) & CD & Serum & $\begin{array}{l}\text { LPE } 22: 6, \text { LPE } 24: 6 \\
\text { LPC 18:2, LPC } 20: 4 \text {, LPC } 22: 6\end{array}$ & \\
\hline Sewell et al. (2012) & $C D$ & $\begin{array}{l}\text { Tissue } \\
\text { Cell }\end{array}$ & $\begin{array}{l}\text { PI 16:0/18:1 } \\
\text { PC 16:0/20:4 }\end{array}$ & $\begin{array}{l}\text { The proportion of significant PC were } \\
\text { increased in CD group stimulated } \\
\text { with heat-killed Escherichia coli. }\end{array}$ \\
\hline
\end{tabular}


Lee et al. Lipidomics of Inflammatory Bowel Diseases

Table 5. FA biomarker candidates in studies included in the systematic review of IBD

\begin{tabular}{|c|c|c|c|c|}
\hline Author (year) & IBD type & Sample & FA biomarker candidate & Additional description \\
\hline Manfredi et al. (2019) & $\mathrm{CD} / \mathrm{UC}$ & Serum & $\begin{array}{l}\text { Eicosapentaenoic acid } \\
\text { Docosahexaenoic acid } \\
\text { Linoleic acid } \\
\text { Tridecylic acid } \\
\text { Caprylic acid } \\
\text { Behenic acid } \\
\text { Lignoceric acid } \\
\text { Arachidic acid } \\
\text { Tricosylic acid } \\
\text { Arachidonic acid } \\
\text { Icosadienoic acid } \\
\text { Nervonic acid } \\
\text { Paulinic acid } \\
\text { Suberic acid }\end{array}$ & \\
\hline Horta et al. (2021) & Fatigue CD & Plasma & $\begin{array}{l}\text { Leukotriene B4 } \\
\text { 15S-HpETE } \\
\text { 16R-HETE }\end{array}$ & $\begin{array}{l}\text { FA biomarker candidates in the } 50 \text { most } \\
\text { discriminant biomarkers. }\end{array}$ \\
\hline Guan et al. (2020) & $\mathrm{CD} / \mathrm{UC}$ & Plasma & $\begin{array}{l}\text { 12,13S-EOT } \\
\text { Arachidonic acid } \\
\text { Eicosapentaenoic acid } \\
\text { 5,6-EpETrE } \\
\text { 2-hydroxyglutaric acid } \\
\text { Docosahexaenoic acid } \\
\text { 8,9-EpETrE } \\
\text { 8R-HpODE } \\
\text { Nervonic acid } \\
\text { 9,12,13-TriHOME } \\
\text { Palmitic acid } \\
\text { 2E-decenoyl-CoA } \\
\text { 9-heptadecylenic acid } \\
\text { Traumatic acid } \\
\text { 20-HETE } \\
\text { Cis-9-palmitoleic acid }\end{array}$ & $\begin{array}{l}\text { FA biomarker candidates in the } 55 \text { most } \\
\text { discriminant biomarkers. }\end{array}$ \\
\hline $\begin{array}{l}\text { Bazarganipour et al. } \\
\text { (2019) }\end{array}$ & UC & Plasma & $\begin{array}{l}\text { FA } 16: 0 \text {, FA 18:0, FA 18:1, FA 20:1, FA 20:4, } \\
\text { FA 20:5, FA 22:3, FA 22:4, FA 22:5 } \\
\text { Eicosapentaenoic acid } \\
\text { Docosahexaenoic acid }\end{array}$ & $\begin{array}{l}\text { Although lipidomic analysis was done } \\
\text { by using both plasma and tissue } \\
\text { samples, fatty acid subclass was } \\
\text { revealed only in plasma samples. }\end{array}$ \\
\hline Jansson et al. (2009) & $C D$ & Feces & $\begin{array}{l}\text { Oleic acid } \\
\text { Stearic acid } \\
\text { Palmitic acid } \\
\text { Arachidonic acid } \\
\text { Octadecatrienoic acid } \\
\text { Linoleic acid } \\
\text { Prostaglandin F2 } \alpha \\
\text { 2,3-dinor-8-iso-prostaglandin F2 } \alpha \\
\text { Prostaglandin F1 } \alpha \\
\text { Prostaglandin E2 } \alpha\end{array}$ & \\
\hline Murgia et al. (2018) & CD & Plasma & $\begin{array}{l}\text { FA } 16: 0 \text {, FA } 16: 1 \text {, FA 18:0, FA 18:1, FA 18:2, } \\
\text { FA } 22: 1 \text {, FA 24:2, FA } 24: 3\end{array}$ & \\
\hline
\end{tabular}


Table 5. Continued

\begin{tabular}{|c|c|c|c|c|}
\hline Author (year) & IBD type & Sample & FA biomarker candidate & Additional description \\
\hline Bene et al. (2006) & UC & Plasma & $\begin{array}{l}\text { Propionylcarnitine } \\
\text { Butyrylcarnitine } \\
\text { Isovalerylcarnitine } \\
\text { Octenoylcarnitine } \\
\text { Decanoylcarnitine } \\
\text { Myristoleylcarnitine } \\
\text { Palmitoylcarnitine } \\
\text { Oleylcarnitine } \\
\text { Hydroxyoleylcarnitine }\end{array}$ & \\
\hline Pearl et al. (2014) & UC & Tissue & $\begin{array}{l}\text { Linoleic acid } \\
\text { a-Linolenic acid } \\
\text { Arachidonic acid } \\
\text { Eicosapentaenoic acid } \\
\text { Docosahexaenoic acid } \\
\text { Docosapentaenoic acid }\end{array}$ & \\
\hline Scoville et al. (2018) & $C D$ & Serum & Not specifically mentioned & $\begin{array}{l}\text { Long chain, polyunsaturated, branched } \\
\text { chain, and monohydroxy fatty acids } \\
\text { are the FA biomarker candidates. }\end{array}$ \\
\hline Tefas et al. (2020) & $C D$ & Serum & $\begin{array}{l}\text { Linoleamide } \\
\text { Palmitorylamide } \\
\text { Palmitoleamide } \\
\text { Branched fatty acid esters of hydroxy fatty } \\
\text { acids } \\
\text { Stearyl palmitoleate, Palmitoleyl stearate, } \\
\text { Oleyl palmitate }\end{array}$ & \\
\hline Masoodi et al. (2013) & UC & Tissue & $\begin{array}{l}5 \text {-HETE } \\
\text { 15-HETE } \\
\text { Prostaglandin E2 } \\
\text { Prostaglandin D2 } \\
\text { Thromboxane B2 }\end{array}$ & \\
\hline Lai et al. (2019) & $C D$ & Serum & $\begin{array}{l}\text { Docosahexaenoic acid } \\
\text { Linolenic acid } \\
\text { Arachidonic acid } \\
\text { Pelargonic acid } \\
\text { Propionylcarnitine } \\
\text { Butyrylcarnitine } \\
\text { Isovalerylcarnitine } \\
\text { Heptanoylcarnitine }\end{array}$ & \\
\hline
\end{tabular}

is a key factor regulating intestinal immune responses. Moreover, gut microbes might control SLs, thereby affecting host immunity. Further, during electrospray ionization, it was detected that SMs and Cers form both positive ion and negative ions. In positive mode detection, $[\mathrm{M}+\mathrm{H}]^{+}$was representatively produced by $\mathrm{SMs}$ and $\left[\mathrm{M}+\mathrm{NH}_{4}\right]^{+}$was produced by Cers. In negative mode detection, SMs formed $\left[\mathrm{M}+\mathrm{HCOO}^{-}\right.$ion, and Cers formed $[\mathrm{M}-\mathrm{H}]^{-}$ion. Certain studies included in this systematic review explored the roles of SLs in intestinal inflammation by analyzing blood and tissue samples from UC patients. Bazarganipour et al. (2019) reported that blood fatty acids, lysophosphatidylcholines (LPCs), triglycerides (TGs), and SL profiles significantly changed in response to IBD. Colon tissue samples and blood samples were also used to investigate SLs via LC-MS/MS. The tissue and blood samples were examined separately under different conditions. Certain SLs were markedly elevated in IBD patients compared with healthy controls. Hence, a decline in SLs might contribute to the onset of UC. Another study focusing on UC proposed that SLs may serve as key immunomodulators. However, this report was excluded from our review as the analyses therein were conducted on mice rather than humans. The study nonetheless demonstrated that bioactive SLs regulate innate immunity and are future therapeutic targets (Espaillat et al., 2018). The UC-induced 
Table 6. SM biomarker candidates in studies included in the systematic review of IBD

\begin{tabular}{|c|c|c|c|c|}
\hline Author (year) & IBD type & Sample & SM biomarker candidate & Additional description \\
\hline Horta et al. (2021) & CD & Plasma & $\begin{array}{l}\text { SM d18:4/22:3, SM d18:4/22:4 } \\
\text { CerNS d18:1/24:1 }\end{array}$ & $\begin{array}{l}\text { GP biomarker candidates having odd carbor } \\
\text { number of fatty acid chain are excluded. } \\
\text { FA biomarker candidates in the } 50 \text { most } \\
\text { discriminant biomarkers. }\end{array}$ \\
\hline Guan et al. (2020) & CD/UC & Plasma & $\begin{array}{l}\text { Sphingosine-1-phosphocholine } \\
\text { (3'-sulfo)Galbeta-Cer(d18:1/16:0) }\end{array}$ & \\
\hline Daniluk et al. (2019) & CD & Serum & $\begin{array}{l}\text { SM } 30: 1, \text { SM 32:1, SM 32:2, SM 34:1, } \\
\text { SM } 34: 2 \\
\text { Lactosylceramide 18:1/16:0 }\end{array}$ & $\begin{array}{l}\text { GP biomarker candidates having odd carbon } \\
\text { number of fatty acid chain are excluded. }\end{array}$ \\
\hline Diab et al. (2019) & UC & Tissue & Cer d18:1/24:0, Cer d18:1/24:2 & \\
\hline Fan et al. (2015) & $\mathrm{CD} / \mathrm{UC}$ & Plasma & $\begin{array}{l}\text { Dihydroceramide } \\
\text { Monohexosylceramide } \\
\text { Trihexosylceramide }\end{array}$ & $\begin{array}{l}\text { Dihydroceramide, monohexosylceramide } \\
\text { subclass were relatively significant only } \\
\text { between CD versus control group. }\end{array}$ \\
\hline $\begin{array}{l}\text { Bazarganipour et al. } \\
\text { (2019) }\end{array}$ & UC & Tissue & $\begin{array}{l}\text { Sph, dhSph, S1P, SA1P } \\
\text { C16:0-Cer, C20:0-Cer, C18:0-Cer, C24:1- } \\
\text { Cer } \\
\text { C16:0-GlcCer, C18:0-GlcCer, C24:1- } \\
\text { GlcCer, C16:0-LacCer, C18:0-LacCer, } \\
\text { C24:0-LacCer } \\
\text { C16:0-lactosyl-ceramide, C24:0-lactosyl- } \\
\text { ceramide }\end{array}$ & \\
\hline Braun et al. (2009) & $\mathrm{CD} / \mathrm{UC}$ & Tissue & Not specifically mentioned & $\begin{array}{l}\text { Only total SM can discriminate CD, UC ver- } \\
\text { sus control. }\end{array}$ \\
\hline Tefas et al. (2020) & CD & Serum & Cer d18:0/18:0 & \\
\hline
\end{tabular}

mouse model was treated with bacterial cerastrol, which has anti-inflammatory and antitumor properties (Wang et al., 2016). In that study, $S M(d 18: 1 / 16: 0)$ and $S M(d 18: 1 / 18: 0)$ as well as LPC were stochastically introduced as markers. This report was also omitted from our review as it analyzed mouse rather than human samples (Lee et al., 2017). Studies reporting SLs as biomarker candidate for discriminating IBD are organized in Table 6.

\section{CONCLUSIONS}

Currently, CD and UC are usually diagnosed on the basis of clinical findings. As the global incidence of IBD is increasing, there is an urgent need for novel IBD biomarkers. To the best of our knowledge, the present review is the first to address a lipidomics approach toward IBD diagnosis and staging. A major limitation of this review was the small number of studies included. Reliability could be enhanced by improving the screening and quality assessment of the reports included. In this review, we categorized IBD as CD or UC and selected studies that had implemented a lipidomics approach on various biological samples collected from IBD patients. Several articles focused on pathological alterations in the fatty acid groups, such as eicosanoids, glycerophospholipids, and sphingolipids that compose the membranes lining the gastrointestinal tract. Most of the studies analyzed blood and tissue samples. Further research is required to optimize the appropriate selection of systemic and localized specimens. More- over, to draw a detailed map of lipid classes involved in the associated pathways, future investigations should focus on the implementation of high-resolution MS to analyze the lipid classes implicated in IBD progression. It is believed that the application of lipidomics will provide deeper insights into the pathogenesis, etiology, and molecular mechanisms of IBD.

\section{ACKNOWLEDGMENTS}

This research was supported by the National Research Foundation of Korea (NRF) grant funded by the Korean government (MSIP) (NRF-2018R1A5A2024425).

\section{REFERENCES}

Baumgart, D. C. and Carding, S. R. (2007) Inflammatory bowel disease: cause and immunobiology. Lancet 369, 1627-1640.

Baumgart, D. C. and Sandborn, W. J. (2007) Inflammatory bowel disease: clinical aspects and established and evolving therapies. Lancet 369, 1641-1657.

Bazarganipour, S., Hausmann, J., Oertel, S., El-Hindi, K., Brachtendorf, S., Blumenstein, I., Kubesch, A., Sprinzl, K., Birod, K., Hahnefeld, L., Trautmann, S., Thomas, D., Herrmann, E., Geisslinger, G., Schiffmann, S. and Grösch, S. (2019) The lipid status in patients with ulcerative colitis: sphingolipids are disease-dependent regulated. J. Clin. Med. 8, 971.

Bene, J., Komlósi, K., Havasi, V., Talián, G., Gasztonyi, B., Horváth, K., Mózsik, G., Hunyady, B., Melegh, B. and Figler, M. (2006) Changes of plasma fasting carnitine ester profile in patients with ulcerative 
colitis. World J. Gastroenterol. 12, 110-113.

Bennike, T., Birkelund, S., Stensballe, A. and Andersen, V. (2014) Biomarkers in inflammatory bowel diseases: current status and proteomics identification strategies. World J. Gastroenterol. 20, 3231-3244.

Braun, A., Treede, I., Gotthardt, D., Tietje, A., Zahn, A., Ruhwald, R., Schoenfeld, U., Welsch, T., Kienle, P., Erben, G., Lehmann, W. D., Fuellekrug, J., Stremmel, W. and Ehehalt, R. (2009) Alterations of phospholipid concentration and species composition of the intestinal mucus barrier in ulcerative colitis: a clue to pathogenesis. Inflamm. Bowel Dis. 15, 1705-1720.

Bryan, P. F., Karla, C., Edgar Alejandro, M. T., Sara Elva, E. P., Gemma, F. and Luz, C. (2016) Sphingolipids as mediators in the crosstalk between microbiota and intestinal cells: implications for inflammatory bowel disease. Mediators Inflamm. 2016, 9890141.

Cajka, T. and Fiehn, O. (2014) Comprehensive analysis of lipids in biological systems by liquid chromatography-mass spectrometry. Trends Analyt. Chem. 61, 192-206.

Daniluk, U., Daniluk, J., Kucharski, R., Kowalczyk, T., Pietrowska, K., Samczuk, P., Filimoniuk, A., Kretowski, A., Lebensztejn, D. and Ciborowski, M. (2019) Untargeted metabolomics and inflammatory markers profiling in children with Crohn's disease and ulcerative colitis-a preliminary study. Inflamm. Bowel Dis. 25, 1120-1128.

Dennis, E. A. and Norris, P. C. (2015) Eicosanoid storm in infection and inflammation. Nat. Rev. Immunol. 11, 511-523.

Diab, J., Hansen, T., Goll, R., Stenlund, H., Ahnlund, M., Jensen, E., Moritz, T., Florholmen, J. and Forsdahl, G. (2019) Lipidomics in ulcerative colitis reveal alteration in mucosal lipid composition associated with the disease state. Inflamm. Bowel Dis. 25, 1780-1787.

Duan, R. D. and Nilsson, A. (2009) Metabolism of sphingolipids in the gut and its relation to inflammation and cancer development. Prog. Lipid Res. 48, 62-72.

Ehehalt, R., Wagenblast, J., Erben, G., Lehmann, W. D., Hinz, U. Merle, U. and Stremmel, W. (2004) Phosphatidylcholine and lysophosphatidylcholine in intestinal mucus of ulcerative colitis patients. A quantitative approach by nanoelectrospray-tandem mass spectrometry. Scand. J. Gastroenterol. 39, 737-742.

Espaillat, M. P., Snider, A. J., Qiu, Z., Channer, B., Coant, N., Schuchman, E. H., Kew, R. R., Sheridan, B. S., Hannun, Y. A. and Obeid, L. M. (2018) Loss of acid ceramidase in myeloid cells suppresses intestinal neutrophil recruitment. FASEB J. 32, 2339-2353.

Ezri, J., Marques-Vidal, P. and Nydegger, A. (2012) Impact of disease and treatments on growth and puberty of pediatric patients with inflammatory bowel disease. Digestion 85, 308-319.

Fahy, E., Subramaniam, S., Murphy, R. C., Nishijima, M., Raetz, C. R. H., Shimizu, T., Spener, F., Van Meer, G., Wakelam, M. J. O. and Dennis, E. A. (2009) Update of the LIPID MAPS comprehensive classification system for lipids. J. Lipid Res. $\mathbf{5 0}$, S9-S14.

Fan, F., Mundra, P. A., Fang, L., Galvin, A., Moore, X. L., Weir, J. M., Wong, G., White, D. A., Chin-Dusting, J., Sparrow, M. P., Meikle, P. J. and Dart, A. M. (2015) Lipidomic profiling in inflammatory bowel disease: comparison between ulcerative colitis and Crohn's disease. Inflamm. Bowel Dis. 21, 1511-1518.

Furlan, A. D., Pennick, V., Bombardier, C. and Van Tulder, M. (2009) 2009 Updated method guidelines for systematic reviews in the cochrane back review group. Spine 34, 1929-1941.

Gallagher, K., Catesson, A., Griffin, J. L., Holmes, E. and Williams, H. R. T. (2021) Metabolomic analysis in inflammatory bowel disease: a systematic review. J. Crohns Colitis 15, 813-826.

Guan, S., Jia, B., Chao, K., Zhu, X., Tang, J., Li, M., Wu, L., Xing, L., Liu, K., Zhang, L., Wang, X., Gao, X. and Huang, M. (2020) UPLCQTOF-MS-based plasma lipidomic profiling reveals biomarkers for inflammatory bowel disease diagnosis. J. Proteome Res. 19, 600609.

Han, X. (2016) Lipidomics for studying metabolism. Nat. Rev. Endocrinol. 12, 668-679.

Horta, D., Moreno-Torres, M., Ramírez-Lázaro, M. J., Lario, S., Kuligowski, J., Sanjuan-Herráez, J. D., Quintas, G., Villoria, A. and Calvet, X. (2021) Analysis of the association between fatigue and the plasma lipidomic profile of inflammatory bowel disease patients. $J$. Proteome Res. 20, 381-392.

Huan, T., Palermo, A., Ivanisevic, J., Rinehart, D., Edler, D., Phom- mavongsay, T., Benton, H. P., Guijas, C., Domingo-Almenara, X., Warth, B. and Siuzdak, G. (2018) Autonomous multimodal metabolomics data integration for comprehensive pathway analysis and systems biology. Anal. Chem. 90, 8396-8403.

Iwatani, S., Iijima, H., Otake, Y., Amano, T., Tani, M., Yoshihara, T., Tashiro, T., Tsujii, Y., Inoue, T., Hayashi, Y., Takeda, K., Hayashi, A., Fujita, S., Shinzaki, S. and Takehara, T. (2020) Novel mass spectrometry-based comprehensive lipidomic analysis of plasma from patients with inflammatory bowel disease. J. Gastroenterol. Hepatol. 35, 1355-1364.

Jansson, J., Willing, B., Lucio, M., Fekete, A., Dicksved, J., Halfvarson, J., Tysk, C. and Schmitt-Kopplin, P. (2009) Metabolomics reveals metabolic biomarkers of Crohn's disease. PLoS ONE 4, e6386.

Lai, Y., Xue, J., Liu, C. W., Gao, B., Chi, L., Tu, P., Lu, K. and Ru, H. (2019) Serum metabolomics identifies altered bioenergetics, signaling cascades in parallel with exposome markers in Crohn's disease. Molecules 24, 449.

Lee, Y., Choo, J., Kim, S. J., Heo, G., Pothoulakis, C., Kim, Y. H. and Im, E. (2017) Analysis of endogenous lipids during intestinal wound healing. PLOS ONE 12, e0183028.

Liebisch, G., Vizcaíno, J. A., Köfeler, H., Trötzmüller, M., Griffiths, W. J., Schmitz, G., Spener, F. and Wakelam, M. J. O. (2013) Shorthand notation for lipid structures derived from mass spectrometry. J. Lipid Res. 54, 1523-1530.

Manfredi, M., Conte, E., Barberis, E., Buzzi, A., Robotti, E., Caneparo, V., Cecconi, D., Brandi, J., Vanni, E., Finocchiaro, M., Astegiano, M., Gariglio, M., Marengo, E. and De Andrea, M. (2019) Integrated serum proteins and fatty acids analysis for putative biomarker discovery in inflammatory bowel disease. J. Proteomics 195, 138-149.

Martin, F. P., Ezri, J., Cominetti, O., Da Silva, L., Kussmann, M., Godin, J. P. and Nydegger, A. (2016) Urinary metabolic phenotyping reveals differences in the metabolic status of healthy and inflammatory bowel disease (IBD) children in relation to growth and disease activity. Int. J. Mol. Sci. 17, 1310.

Masoodi, M., Pearl, D. S., Eiden, M., Shute, J. K., Brown, J. F., Calder P. C. and Trebble, T. M. (2013) Altered colonic mucosal polyunsaturated fatty acid (PUFA) derived lipid mediators in ulcerative colitis: new insight into relationship with disease activity and pathophysiology. PLOS ONE 8, e76532.

McShane, L. M., Cavenagh, M. M., Lively, T. G., Eberhard, D. A., Bigbee, W. L., Williams, P. M., Mesirov, J. P., Polley, M. Y. C., Kim, K. Y., Tricoli, J. V., Taylor, J. M. G., Shuman, D. J., Simon, R. M., Doroshow, J. H. and Conley, B. A. (2013) Criteria for the use of omics-based predictors in clinical trials. 502, 317-320.

Moher, D., Liberati, A., Tetzlaff, J. and Altman, D. G. (2009) Preferred reporting items for systematic reviews and meta-analyses: the PRISMA statement. BMJ 339, b2535.

Molodecky, N. A., Panaccione, R., Ghosh, S., Barkema, H. W. and Kaplan, G. G. (2011) Challenges associated with identifying the environmental determinants of the inflammatory bowel diseases. Inflamm. Bowel Dis. 17, 1792-1799.

Murgia, A., Hinz, C., Liggi, S., Denes, J., Hall, Z., West, J., Santoru, M. L., Piras, C., Manis, C., Usai, P., Atzori, L., Griffin, J. L. and Caboni, P. (2018) Italian cohort of patients affected by inflammatory bowel disease is characterised by variation in glycerophospholipid, free fatty acids and amino acid levels. Metabolomics 14, 140.

Ng, S. C., Shi, H. Y., Hamidi, N., Underwood, F. E., Tang, W., Benchimol, E. I., Panaccione, R., Ghosh, S., Wu, J. C. Y., Chan, F. K. L., Sung, J. J. Y. and Kaplan, G. G. (2017) Worldwide incidence and prevalence of inflammatory bowel disease in the 21st century: a systematic review of population-based studies. Lancet 390, 27692778.

Pearl, D. S., Masoodi, M., Eiden, M., Brümmer, J., Gullick, D., Mckeever, T. M., Whittaker, M. A., Nitch-Smith, H., Brown, J. F., Shute, J. K., Mills, G., Calder, P. C. and Trebble, T. M. (2014) Altered colonic mucosal availability of $n-3$ and $n-6$ polyunsaturated fatty acids in ulcerative colitis and the relationship to disease activity. J. Crohns Colitis 8, 70-79.

Roberts, L. D., McCombie, G., Titman, C. M. and Griffin, J. L. (2008) A matter of fat: an introduction to lipidomic profiling methods. $J$. Chromatogr. B Analyt. Technol. Biomed. Life Sci. 871, 174-181.

Sauer, C. G. and Kugathasan, S. (2009) Pediatric inflammatory bowel 
disease: highlighting pediatric differences in IBD. Gastroenterol. Clin. North Am. 38, 611-628.

Schneider, H., Braun, A., Füllekrug, J., Stremmel, W. and Ehehalt, R. (2010) Lipid based therapy for ulcerative colitis-modulation of intestinal mucus membrane phospholipids as a tool to influence inflammation. Int. J. Mol. Sci. 11, 4149-4164.

Scoville, E. A., Allaman, M. M., Brown, C. T., Motley, A. K., Horst, S. N., Williams, C. S., Koyama, T., Zhao, Z., Adams, D. W., Beaulieu, D. B., Schwartz, D. A., Wilson, K. T. and Coburn, L. A. (2018) Alterations in lipid, amino acid, and energy metabolism distinguish Crohn's disease from ulcerative colitis and control subjects by serum metabolomic profiling. Metabolomics 14, 17.

Sewell, G. W., Hannun, Y. A., Han, X., Koster, G., Bielawski, J., Goss, V., Smith, P. J., Rahman, F. Z., Vega, R., Bloom, S. L., Walker, A. P., Postle, A. D. and Segal, A. W. (2012) Lipidomic profiling in Crohn's disease: abnormalities in phosphatidylinositols, with preservation of ceramide, phosphatidylcholine and phosphatidylserine composition. Int. J. Biochem. Cell Biol. 44, 1839-1846.

Storr, M., Vogel, H. J. and Schicho, R. (2013) Metabolomics: is it useful for inflammatory bowel diseases? Curr. Opin. Gastroenterol. 29, 378-383.

Tefas, C., Ciobanu, L., Tanțău, M., Moraru, C. and Socaciu, C. (2020)
The potential of metabolic and lipid profiling in inflammatory bowel diseases: a pilot study. Bosn. J. Basic Med. Sci. 20, 262-270.

Titz, B., Gadaleta, R. M., Lo Sasso, G., Elamin, A., Ekroos, K., Ivanov, N. V., Peitsch, M. C. and Hoeng, J. (2018) Proteomics and lipidomics in inflammatory bowel disease research: from mechanistic insights to biomarker identification. Int. J. Mol. Sci. 19, 2775.

Van Nuenen, M. H. M. C., Venema, K., Van Der Woude, J. C. J. and Kuipers, E. J. (2004) The metabolic activity of fecal microbiota from healthy individuals and patients with inflammatory bowel disease. Dig. Dis. Sci. 49, 485-491.

Wang, R., Gu, X., Dai, W., Ye, J., Lu, F., Chai, Y., Fan, G., Gonzalez, F. J., Duan, G. and Qi, Y. (2016) A lipidomics investigation into the intervention of celastrol in experimental colitis. Mol. Biosyst. 12, 1436-1444.

Williams, H. R., Cox, I. J., Walker, D. G., Cobbold, J. F., Taylor-Robinson, S. D., Marshall, S. E. and Orchard, T. R. (2010) Differences in gut microbial metabolism are responsible for reduced hippurate synthesis in Crohn's disease. BMC Gastroenterol. 10, 108.

Zhang, C., Wang, K., Yang, L., Liu, R., Chu, Y., Qin, X., Yang, P. and Yu, H. (2018) Lipid metabolism in inflammation-related diseases. Analyst 143, 4526-4536. 